\title{
POLITIK HUKUM KETERBUKAAN INFORMASI PUBLIK DALAM MEWUJUDKAN TATA KELOLA PEMERINTAHAN YANG BAIK DI PEMERINTAH DAERAH KABUPATEN WONOGIRI
}

\author{
Gabriel Vian Mukti Hutomo Raharjo \\ e-mail: vian.mukti@gmail.com \\ Pegawai Dinas Perhubungan Kabupaten Wonogiri \\ Sunny Ummul Firdaus \\ e-mail: firdaussunny@yahoo.com \\ Agus Riwanto \\ e-mail: agusriewanto@yahoo.com \\ Dosen Fakultas Hukum UNS Surakarta
}

\begin{abstract}
This article examine how important of Public Disclosure to create good governance after the enactment Act of Public Disclosure Number 14 of 2008. This study also analyse Legal Policy of Public Disclosure to create good governance at Regional Government of Wonogiri. This research is normative research that supported by empirics data. Base on this study showed that the Act of Public Disclosure is a consequense of nation task as mandated in 1945 Constitution. Public Disclosure fulfillment as one of Human Rights which is guaranteed and protected by the state. Fulfillment of Public Disclosure has a philosohical, sociological and juridical meaning. Good Governance is requirement for each goverment to realize the asporations of society and reach the goal as well as the aspirations of the nation. The implementation of Public Disclosure at Regional Government of Wonogiri depend on legal policy and publik policy. The nation that did good governance would have good public policy. Good public policy created the welfare for the citizens.
\end{abstract}

Keywords: Law policy; public disclosure; good governance; and regional autonomy.

\begin{abstract}
Abstrak
Artikel ini mengkaji tentang pentingnya Keterbukaan Informasi Publik dalam mewujudkan tata kelola pemerintahan yang baik setelah disahkannya Undang-Undang Nomor 14 Tahun 2008 tentang Keterbukaan Informasi Publik (UU KIP). Penelitian ini menganalisis Politik Hukum berkaitan dengan Keterbukan Informasi Publik dalam mewujudkan tata kelola pemerintahan yang baik di Pemerintah Daerah Kabupaten Wonogiri. Penelitian ini adalah penelitian hukum normatif yang ditunjang dengan data-data empiris. Berdasarkan penelitian ini diperoleh hasil bahwa UU KIP merupakan perwujudan pelaksanaan tugas negara sebagaimana diamanatkan dalam UUD 1945. Pemenuhan Informasi Publik merupakan salah satu Hak Asasi Manusia yang dijamin dan dilindungi oleh negara. Pembentukan UU KIP mempunyai makna yang penting secara filosofis, soiologis dan yuridis. Terselenggaranya tata kelola pemerintahan yang baik merupakan syarat bagi setiap pemerintahan untuk mewujudkan aspirasi masyarakat dan mencapai tujuan serta citacita bangsa dan negara. Implementasi UU KIP di Kabupaten Wonogiri yang responsif tergantung dari politik hukum dan kebijakan publik yang diambil oleh pemerintah daerah. Negara yang
\end{abstract}


melakukan tata kelola pemerintahan yang baik akan menghasilkan kebijakan publik yang baik. Kebijakan publik yang baik akan menghasilkan kesejahteraan bagi masyarakat.

Kata kunci: politik hukum; keterbukaan informasi publik; tata kelola pemerintahan yang baik; dan otonomi daerah.

\section{A. Pendahuluan}

Di era globalisasi akses terhadap segala informasi sangat terbuka dan seakan tanpa batas. Bentuk tanggung jawab penyelenggaraan negara adalah dengan adanya keterbukaan informasi publik. Salah satu ciri pemerintah yang demokratis ialah pemerintah yang patuh pada norma hukum, menghormati nilai-nilai HAM dan mempunyai kekuasaan yang terbatas (King Faisal Sulaiman, 2014: 20). Spirit keterbukaan penyelenggaraan pemerintahan berjalan beriringan dan memiliki hubungan kausal dengan semangat reformasi yang digulirkan sejak 1998. Terutama dalam upaya memberantas penyakit kolusi, korupsi, dan nepotisme. Orang yang memberikan informasi tentang adanya perbuatan kolusi, korupsi, dan nepotisme bukan harus saja dilindungi hukum, tetapi juga berhak mendapat penghargaan. Prinsip ini sebenarnya menunjukkan pentingnya sebuah keterbukaan informasi (Tim Penyusun Komisi Informasi Pusat Republik Indonesia, Indonesian Center for Enviromental Law (ICEL) dan Yayasan Tifa, 2009: 6).

Konteks informasi sebagai bagian dari hak asasi manusia merujuk pada UndangUndang Nomor 39 Tahun 1999 tentang Hak Asasi Manusia. Peraturan perundangundangan tersebut hanya memuat prinsipprinsip dasar perlunya keterbukaan informasi. Pada praktiknya, kebutuhan atas informasi membawa implikasi yang jauh lebih luas dan kompleks. Langkah awal Pemerintah Indonesia dalam mewujudkan good governance adalah melakukan reformasi dalam segala kegiatan pemerintahan ataupun pelayanan publik melalui pemanfaatan teknologi informasi atau biasa disebut dengan e-government yang mulai dicanangkan tanggal 24 April 2001 melalui Instruksi Presiden Nomor 6 Tahun 2001 tentang Telematika (Telekomunikasi, Media dan Informatika), yang menjelaskan bahwa aparat pemerintah harus menggunakan telematika dalam mewujudkan good governance dan mempercepat proses demokrasi (Nico andrianto, 2007: 1).

Melalui pembahasan yang panjang selama beberapa tahun, pada tanggal 30 April 2008, dikeluarkan Undang-Undang Nomor 14 Tahun 2008 tentang Keterbukaan Informasi Publik (selanjutnya disebut dengan UU KIP). UU KIP adalah UndangUndang yang memberikan jaminan terhadap semua orang untuk memperoleh informasi publik dalam rangka mewujudkan serta meningkatkan peran serta aktif masyarakat dalam penyelenggaraan negara, baik pada tingkat pengawasan penyelenggaraan negara maupun pada tingkat perlibatan masyarakat dalam proses pengambilan kebijakan publik (Nunuk Febriananingsih, 2012: 136).

Beberapa kendala dalam implementasi Keterbukaan Informasi Publik yaitu adanya ketentuan Pasal 6 UU KIP yang menyatakan bahwa badan publik berhak menolak permintaan informasi masyarakat apabila informasi yang diminta salah satu data tersebut belum dikuasai atau didokumentasikan oleh badan publik. Kondisi ini memperlemah akses publik terhadap data-data publik. Kendala yang lain dalam implementasinya memunculkan sengketa informasi antara badan publik dengan pemohon informasi. Dalam hal ini badan publik berhak untuk menolak memberikan informasi dengan menggunakan 
alasan Pasal 17 UU KIP yang mengatur tentang informasi yang dikecualikan.

Tingkat keterbukaan informasi pada badan publik dapat dilihat dari Data Partisipasi Badan Publik dari tahun 2013 hingga tahun 2015 yang cenderung meningkat yakni pada tahun 2013 sebesar 38\%, tahun 2014 sebesar 40\% dan pada tahun 2015 sebesar $47 \%$ (https://www.komisiinformasi.go.id. Diakses tanggal 14 Oktober 2016). Walaupun terjadi peningkatan partisipasi Badan Publik, secara keseluruhan implementasi UU KIP belum bisa dilaksanakan sepenuhnya sampai ke tingkat daerah.

Salah satu faktor penting dalam pelaksanaan UU KIP adalah bagaimana kapasitas setiap badan publik dalam memahami UU KIP itu sendiri. Berkenaan dengan upaya pelayanan dan mewujudkan kesejahteraan rakyat, birokrasi publik memberikan andil yang relatif besar. Semua yang terdapat dalam skup penyelenggaraan negara tidak terlepas dari konteks public services dan public affairs (Ambar Teguh Sulistiyani dan Yermias T. Keban, 2011: 1). Efektivitas penyelenggaraan otonomi daerah dan kesibukannya tidak cukup hanya bila dikaitkan dengan persoalan bangsa yang bersifat domestik, tetapi juga dengan konteks global (Syakarani dan Syahriani, 2009: 6).

Dalam rangka penyelenggaraan pemerintah daerah sesuai dengan amanat UUD Negara RI Tahun 1945 maka kebijakan politik hukum yang ditempuh oleh pemerintah terhadap pemerintah daerah diarahkan untuk mempercepat terwujudnya kesejahteraan masyarakat melalui peningkatan pelayanan, pemberdayaan, dan peran serta masyarakat, serta peningkatan daya saing daerah, dengan mempertimbangkan prinsip demokrasi, pemerataan, keadilan, keistimewaan, dan kekhususan suatu daerah dalam sistem Negara Kesatuan Republik Indonesia (NKRI) (Siswanto Sunarno, 2006: 2).
Pemerintah Daerah Kabupaten Wonogiri telah menerbitkan regulasi yang menjamin hak setiap orang untuk memperoleh informasi publik dalam rangka mendorong partisipasi masyarakat dalam pengambilan keputusan publik untuk mewujudkan penyelenggaraan pemerintahan daerah yang baik. Implementasi UU KIP masih belum maksminal disebabkan adanya kendala atau hambatan. Berdasarkan hal-hal yang telah diuraikan di atas, maka dalam artikel ini penulis membahas lebih dalam lagi mengenai politik hukum keterbukaan informsi publik dalam mewujudkan tata kelola pemerintahan yang baik di Pemerintah Daerah Kabupaten Wonogiri”.

\section{B. Metode Penelitian}

Jenis penelitian yang digunakan dalam penelitian ini adalah penelitian hukum normatif yang ditunjang dengan data-data empiris. Penelitian ini menggunakan konsep hukum sebagai norma-norma positif di dalam sistem perundang-undangan hukum nasional, serta konsep hukum sebagai pola-pola perilaku sosial yang terlembaga eksis sebagai variabel sosial yang empirik dan menggunakan analisis motode kualitatif. Bentuk penelitian ini adalah prespektif dan evaluatif. Berdasarkan sifatnya, penelitian dalam penulisan hukum ini merupakan penelitian eksplanatif dan eksploratif. Penelitian ini bertujuan untuk menerangkan mengenai implementasi Undang-Undang Keterbukaan Informasi Publik dalam politik hukum menuju good governance di Kabupaten Wonogiri. Jenis dan Sumber Data terdiri dari data primer dan data sekunder.

\section{Hasil Penelitian dan Pembahasan}

1. Urgensi Keterbukaan Informasi Publik Dalam Mewujudkan Tata Kelola Pemerintahan Yang Baik

Salah satu tantangan besar yang dihadapi Bangsa Indonesia dalam otonomi 
daerah ialah membenahi segala kemelut akibat derasnya arus globalisasi. Ada beberapa anggapan bahwa globalisasi sebagai pembawa masalah bagi kehidupan bangsa, namun kita tidak bisa menghindari masuknya globalisasi ke dalam ranah kehidupan bangsa ini. Dengan mengambil kebijakan yang tepat dalam rangka mengikuti arus globalisasi yang masuk akan senantiasa memberikan manfaat bagi kehidupan (Endang Retnowati, 2012: 54).

Asas-asas umum penyelenggaraan negara dapat kita lihat dalam ketentuan Pasal 3 Undang-Undang Nomor 28 Tahun 1999 tentang Penyelenggaraan Negara yang Bersih dan Bebas dari Korupsi, Kolusi, dan Nepotisme. Salah satu asas penyelenggaraan negara dalam rangka menciptakan tata kelola pemerintahan yang baik (good governance) adalah asas keterbukaan. Keterbukaan dalam hal ini dimaknai sebagai wujud transparansi penyelenggaraan negara terhadap masyarakat, khususnya terkait dengan segala informasi berkaitan dengan pelaksanaan pemerintahan.

Tata kelola pemerintahan yang baik menjadi fenomena di Indonesia setelah krisis ekonomi 1998, yang mana pada saat itu pemerintah mengeluarkan kebijakan untuk memberantas korupsi, kolusi, dan nepotisme (Diaswati Mardiasmo, 2007: 185). Era Reformasi ditandai dengan adanya tuntutan tata kelola kepemerintahan yang baik (Good Governance) yang mensyaratkan adanya transparasi, efektitivitas dan efisiensi, akuntabilitas dan partisipasi masyarakat dalam setiap proses terjadinya kebijakan publik. Setiap Badan Publik sebagaimana diamanatkan dalam Undang-Undang Nomor 14 Tahun 2008 Pasal 7 ayat (3) wajib membangun dan mengembangkan sistem informasi dan dokumentasi untuk mengelola informasi publik secara baik dan efisien sehingga layanan informasi dapat memberikan akses dengan mudah.

Secara filosofis, tugas dari negara sesuai dengan amanat UUD 1945 yang terdapat dalam Pembukaan adalah melindungi segenap bangsa dan seluruh tumpah darah indonesia dan untuk memajukan kesejahteraan umum, mencerdaskan kehidupan bangsa. Seiring dengan perkembangan globalisasi dan era otonomi daerah, maka negara berkewajiban untuk menjamin terhadap pemenuhan Hak Asasi Manusia. Hak untuk memperoleh informasi merupakan salah satu Hak Asasi Manusia yang mana pada saat ini merupakan salah satu kebutuhan yang pokok dalam rangka penyelenggaraan negara.

Hadirnya Undang-Undang Nomor 14 Tahun 2008 tentang Keterbukaan Informasi Publik merupakan tonggak penting bagi perkembangan demokrasi di Indonesia. Tujuan dibuatnya undangundang ini adalah untuk menjamin kebebasan informasi yang diharapkan menjadi spirit demokratisasi yang menawarkan kebebasan sekaligus tanggung jawab secara bersamaan. Secara sosiologis, kebebasan informasi di satu sisi mendorong akses publik terhadap informasi secara luas. Sementara di sisi yang lain, kebebasan informasi juga sekaligus dapat membantu memberikan pilihan langkah yang jelas bagi pemerintah dalam mengambil suatu kebijakan secara startegis.

Sebagai sebuah bentuk freedom of information act, UU KIP ini mengatur pemenuhan kebutuhan informasi yang terkait dengan kepentingan publik. Kehadiran UU KIP sekaligus memberikan penegasan bahwa keterbukaan informasi publik bukan saja merupakan bagian 
dari hak asasi manusia secara universal, namun juga merupakan constitutional rights sebagaimana dinyatakan dalam Pasal 28F UUD 1945 (Sofian Munawar Asgart. http://www.kompasiana. com/ sasgart/keterbukaan-informasipublik-dalam-perspektif-governability 550d9689813311c925b1e2c0. Diakses tanggal 15 November 2016).

\section{Pasal 28F}

Setiap orang berhak untuk berkomunikasi dan memperoleh informasi untuk mengembangkan pribadi dan lingkungan sosialnya, serta berhak untuk mencari, memperoleh, memiliki, menyimpan, mengolah, dan menyampaikan informasi dengan menggunakan segala jenis saluran yang tersedia.

Keterbukaan informasi memberi peluang bagi rakyat untuk berpartisipasi dalam berbagai kebijakan publik. Data pengaduan masyarakat kepada Komisi Pemberatasan Korupsi dari tahun 2004 sampai dengan tahun 2016 mengalami peningkatan, yaitu pada tahun 2004 terdapat 2.281 pengaduan yang cenderung meningkat dari tahun ketahun sampai pada tahun 2016 terdapat 7.271 pengaduan (www.kpk.go.id, diakses pada tanggal 24 April 2017). Bahkan jumlah pengaduan dari masyarakat telah meningkat signifikan pada tahun 2008 sebanyak 8.699 pengaduan, sedangkan jumlah pengaduan tertinggi pada tahun 2014 sebanyak 9.432 pengaduan. Dengan semakin meningkatnya jumlah pengaduan masyarakat dalam kasus korupsi menggambarkan perilaku kesadaran masyarakat untuk berpartisipasi dalam penegakan hukum sebagai wujud pelaksanaan kebebasan informasi. Sedangkan disisi lain perbuatan korupsi masih menjadi budaya dalam penyelenggaraan pemerintahan baik di tingkat pusat sampai ke daerah yang belum bisa dihilangkan bahkan cenderung meningkat.

Eksistensi regulasi mengenai Keterbukaan Informasi Publik dapat mendorong suatu masyarakat menjadi lebih demokratis dengan memungkinkan adanya akses masyarakat terhadap informasi yang dimiliki pemerintah maupun lembaga-lembaga publik lain. Semangat ketebukaan harus menjadi prinsip yang dipegang oleh para penyelenggara negara dan para penegak hukum untuk memperoleh kepercayaan dari rakyat (Laperdrix Marie, 2011: 8).

Secara garis besar pentingnya Keterbukaan Informasi Publik dalam mewujudkan tata kelola pemerintahanyang baik dapat dilihat dari tujuan yang terdapat dalam Pasal 3 UU KIP, yaitu:

a. Warga negara dijamin haknya untuk mengetahui rencana pembuatan kebijakan publik, program kebijakan publik, dan proses pengambilan keputusan publik, serta alasan pengambilan suatu keputusan publik.

b. Masyarakat didorong untuk berpartisipasi dalam proses pengambilan kebijakan publik.

c. Peran aktif masyarakat semakin meningkat dalam pengambilan kebijakan publik dan pengelolaan Badan Publik yang baik.

d. Penyelenggaraan negara yang baik dapat diwujudkan, yaitu transparan, efektif dan efisien, akuntabel serta dapat dipertanggungjawabkan.

e. Setiap kebijakan publik dari penyelenggara negara yang mempengaruhi hajat hidup orang banyak dapat diketahui alasannya.

f. Dengan adanya keterbukaan informasi diharapkan turut memberikan 
andil dalam perkembangan ilmu pengetahuan dan mencerdaskan kehidupan bangsa.

g. Adanya peningkatan pengelolaan dan pelayanan informasi di lingkungan Badan Publik untuk menghasilkan layanan informasi yang berkualitas.

UU KIP mengamanatkan pembentukan komisi Informasi. Salah satu peran Komisi Informasi dapat dilihat pada kasus sengketa informasi yang masuk Komisi Informasi Provinsi Jawa Tengah selama tahun anggaran 2016 sebanyak 36 kasus. Apabila dibandingkan dari tahun 2015 terjadi peningkatan sebanyak 11 kasus. Berdasarkan data tersebut, terdapat kenaikan dalam jumlah pengajuan proses penyelesaian sengketa informasi pada tahun 2016 dibandingkan dengan tahun 2015. Permohonan penyelesaian sengketa informasi publik tahun 2016 yang didaftarkan ke Komisi Informasi Provinsi Jawa Tengah lebih didominasi oleh LSM dibandingkan individu ataupun kelompok orang (www.kipjateng.jatengprov.go.id. Diakses tanggal 17 Maret 2017).

Pendayagunaan TIK yang ada pada sistem kepemerintahan, diharapkan dapat membawa sistem kepemerintahan yang transparansi, efisiensi, efektifitas dan akuntabilitas, sehingga kemajuan TIK dianggap salah satu cara yang sangat diperlukan pemerintah dalam peningkatan pelayanan, pendayagunaan serta menciptakan pengelolaan pemerintah yang transparansi, efisiensi, efektifitas dan akuntabilitas. penggunaan TIK di dalam lingkungan pemerintah disebut E-Government (Siska Setiya Dewi, dkk, 2014: 2). UNDP mendefinisikan E-Government adalah penggunaan teknologi informasi dan komunikasi (ICT-Information and Communication Technology) oleh pihak pemerintahan.
Pelaksanaan E-Goverment dalam tata kelola pemerintahan di Indonesia ditegaskan melalui Instruksi Presiden Nomor 3 Tahun 2003 tentang Kebijakan dan Strategi Nasional Pengembangan E-Government.

Pemanfaatan teknologi informasi pada pemerintahan bertujuan untuk mendukung penyelenggaraan tata kelola organisasi yang lebih baik, sehingga mampu menyediakan layanan informasi tepat guna bagi stakeholder. Layanan digitalisasi pemerintah dapat dilaksanakan melalui pemanfaatan internet. Misalnya layanan pengaduan masyarakat berbasis sms, absensi online (e-absensi), laporan kinerja SKPD (e-laporan), persuratan (e-office) yang kesemua layanan tersebut terpublish pada web induk pemerintah daerah, sekaligus bisa digunakan sebagai alat untuk monitoring dan evaluasi kinerja dilingkup Pemerintah tingkat satuan kerja perangkat daerah (SKPD) (Diah Rachma Aprianty, 2016: 1591).

Dampak positif yang menjadikan pentingnya UU KIP, seperti transparansi dan akuntabilitas badan-badan publik, akselerasi pemberantasan KKN, optimalisasi perlindungan hak-hak masyarakat terhadap pelayanan publik, persaingan usaha secara sehat, terciptanya pemerintahan yang baik dan tata kelola badan-badan publik dan akselerasi demokratisasi. Keterbukaan informasi publik yang dijalankan dengan baik oleh Pemerintah/Badan publik akan menjadi media promosi seperti iklan, bahkan kemampuanya akan melampaui bombastisnya iklan dimedia massa. Selain mendukung tranparansi dan partisipasasi masyarakat dalam pengelolaan dan pembangunan, KIP akan menjadi bentuk promosi atau pencitraan yang sangat baik bagi pemerintah atau badan publik 
(Surianto. www.babelprov.go.id. Diakses tanggal 20 Desember 2016).

\section{Politik Hukum Keterbukaan Informasi Publik dalam Mewujudkan Tata Kelola Pemerintahan Yang Baik di Pemerintah Daerah Kabupaten Wonogiri}

Kebijakan dasar tentang Keterbukaan Informasi di Pemerintahan Daerah Kabupaten Wonogiri dapat dilihat dari Rencana Pembangunan Jangka Menengah Daerah (selanjutnya disebut dengan RPJMD) Kabupaten Wonogiri. Pasal 2 Peraturan Daerah Kabupaten Wonogiri Nomor 12 Tahun 2016 tentang Rencana Pembangunan Jangka Menengah Daerah Kabupaten Wonogiri Tahun 2016-2021 menjelaskan bahwa RPJMD merupakan dokumen perencanaan pembangunan daerah sebagai landasan dan pedoman bagi Pemerintah Daerah Kabupaten Wonogiri dalam melaksanakan pembangunan 5 (lima) tahun.

Pasal 4 Peraturan Daerah Kabupaten Wonogiri Nomor 12 Tahun 2016 tentang Rencana Pembangunan Jangka Menengah Daerah Kabupaten Wonogiri Tahun 2016-2021 menjelaskan bahwa RPJMD merupakan penjabaran dari Visi, Misi dan Program Bupati terpilih Tahun 2016 serta Tujuan, sasaran, strategi, arah kebijakan pembangunan, dan program pembangunan yang akan dilaksanakan oleh Pemerintah Daerah, disertai dengan kerangka pendanaan yang bersifat indikatif. Visi Pemerintah Kabupaten Wonogiri Tahun 2016-2021 adalah "Membangun Wonogiri SUKSES, Beriman, Berbudaya, Berkeadilan, Berdaya Saing dan Demokratis”. Dalam rangka membangun dan mengelola pemerintahan di kabupaten Wonogiri di perlukan konsep pengelolaan dan manejemen pemerintahan yang baik, "SUKSES" dalam hal ini adalah sebuah motto Kerja Kabupaten Wonogiri yang telah ada sejak tahun 1986. Sukses bukan sekedar simbol atau Jargon Wonogiri tetapi lebih pada konsep manajemen pengelolaaan dan membangun Wonogiri.

Menurut Mahfud MD politik hukum sebagai kebijaksanaan (legal policy) yang dilaksanakan pemerintah secara nasional. Politik hukum membahas mengapa politik mengintervensi hukum, bagaimana politik mempengaruhi hukum, sistem politik yang bagaimana melahirkan hukum yang bagaimana (Abdul Latif dan Hasbi Ali, 2011: 7). Sedangkan Bernard L. Tanya memposisikan politik hukum diantara realisme hidup dengan tuntutan idealisme. Titik tolak politik hukum, adalah visi hukum. Berdasarkan visi maka dapat diwujudkan format bentuk dan sisi hukum yang dianggap capable untuk mewujudkan visi tersebut.

Pelaksanaan Politik Hukum dengan mengedepankan prinsip-prinsip Keterbukaan Informasi Publik sesuai dengan amanat UU KIP di Kabupaten Wonogiri menjadi urusan yang serius untuk dilaksanakan dalam penyelenggaraan pemerintahan daerah serta pelayanan publik. Komiten dari Kepala Daerah untuk mewujudkan hal tersebut ditindaklanjuti oleh Bidang Komunikasi dan Informatika Dinas Perhubungan, Komunikasi dan Informatika Kabupaten Wonogiri untuk memenuhi amanat UU KIP tersebut. Sebagai Kabupaten dengan luas wilayah terbesar kedua di Jawa Tengah menjadi tantangan tersendiri dalam membuat kebijakan yang tepat untuk membangun infrastruktur yang menunjang penyebarluasan informasi (Wawancara dengan Kepala Dinas Perhubungan, Komunikasi dan Informatika Kabupaten Wonogiri pada tanggal 23 Desember 2016). Implementasi Keterbukaan Informasi Publik dimulai pada tahun 2011 
dengan pembuatan regulasi sebagai teknis pelaksanaan di Kabupaten Wonogiri.

Produk Hukum Keterbukaan Informasi Publik yang telah diterbitkan oleh Pemerintah Daerah Kabupaten Wonogiri antara lain:

a. Peraturan Bupati Wonogiri Nomor 31 Tahun 2011 tentang Pembentukan Layanan Pengadaan Secara Elektronik (LPSE) Kabupaten Wonogiri.

b. Peraturan Bupati Wonogiri Nomor 26 Tahun 2012 tentang Pedoman Pelaksanaan Pengadaan Barang/Jasa Secara Elektronik di Lingkungan Pemerintah Kabupaten Wonogiri.

c. Peraturan Daerah Kabupaten Wonogiri Nomor 1 Tahun 2014 tentang Keterbukaan Informasi Publik.

d. Peraturan Bupati Wonogiri Nomor 52 Tahun 2014 tentang Standar Operasional dan Prosedur Penyelenggaraan Informasi Publik di Lingkungan Pemerintah Kabupaten Wonogiri.

Padmo Wahyono menyatakan bahwa politik hukum adalah kebijakan berkenaan dengan sesuatu yang akan diwujudkan. Potret Politik Hukum di Pemerintah Daerah kabupaten Wonogiri tercermin dalam Program Legislasi Daerah (Prolegda). Pengelolaan informasi yang baik didukung bukan hanya "sistem" melainkan peran penting dari birokrasi yang membidanginya (Shepherd, A. Stevenson, dan A. Flinn, 2010: 343). Kontrol terhadap penyebarluasan informasi publik dilakukan dalam hal terdapat informasi yang dikecualikan. Untuk memberikan kepastian tentang Informasi yang dikecualikan maka pada tahun 2016 telah dibuat Surat Keputusan Bupati Wonogiri Nomor 257 Tahun 2016 tentang Informasi Yang
Dikecualikan di Lingkungan Pemerintah Kabupaten Wonogiri. Proses untuk memformulasikan dan menetapkan daftar Informasi Yang Dikecualikan difasilitasi oleh Bidang Komunikasi dan Informatika pada Dinas Perhubungan, Komunikasi dan Informatika Kabupaten Wonogiri (Wawancara dengan Kepala Bidang Komunikasi dan Informatika pada Dinas Perhubungan, Komunikasi dan Informatika Kabupaten Wonogiri pada tanggal 23 Desember 2016).

Apabila dilihat dalam Raperda Prioritas Kabupaten Wonogiri Tahun 2017 (http://www.dprd-wonogirikab.go.id. Diakses tanggal 7 Desember 2016), politik hukum keterbukaan informasi diterapkan dalam penyelenggaraan pemerintahan antara lain dalam hal penatausahaan keuangan daerah perihal pokok-pokok pengelolaan keuangan daerah serta penyelenggaraan pelayanan publik dalam hal administrasi kependudukan. Penyelenggaraan pemerintahan yang baik sudah semestinya melibatkan peran serta masyarakat sebagai salah satu instrumen kontrol atas kebijakan yang diambil (Meissy Janet Naeku, 2016: 38).

Desentralisasi sangat mungkin telah memberi latar baru bagi pentas korupsi di tingkat lokal, menyangkut bergesernya relasi kekuasaan pusatdaerah atau eksekutif-legislatif yang memunculkan pelaku korupsi baru atau latar belakang dan modus operandi yang semakin bervariasi. Terlepas dari hal tersebut, praktik korupsi secara konsisten terjadi sejak lama sebelum kebijakan desentralisasi diterapkan (Antonius Cahyadi dan Donny Danardono, 2009: 30).

Kasus korupsi yang ditangani oleh penegak hukum dari tahun ke tahun mengalami peningkatan sebagaimana 
data laporan tahunan KPK berdasarkan pengaduan masyarakat yang melalami tren peningkatan semenjak tahun 2004. Meningkatnya kasus korupsi yang ditangani oleh penegak hukum maupun berdasarkan laporan masyarakat memperlihatkan bahwa penegakan hukum terhadap tindak pidana korupsi menjadi tugas yang serius untuk diselesaikan oleh para penegak hukum. Penanganan kasus korupsi tidak hanya dilakukan secara represif namun perlu dilakukan upaya pencegahannya. UU KIP sebagai upaya dari pemerintah untuk mencegah dan menjadi sarana pelaporan kasus korupsi.

UU KIP dibuat untuk membenahi penyelenggaraan negara dalam hal ini adalah penyelenggaraan pemerintahan di daerah. Dengan sistem desentralisasi yang berlasung saat ini membuka peluang yang besar untuk melakukan korupsi. Salah satu kebijakan untuk menanggulangi tindak pidana korupsi adalah dengan adanya Keterbukaan Informasi Publik. Manfaat dari kebebasan informasi bukan untuk mencegak tidak pidana korupsi namun juga berguna untuk mengungkap praktek-praktek korupsi. Praktek korupsi yang bisa dirasakan oleh masyarakat secara langsung dalam hal pelayanan publik. Dalam hal penyelenggaraan pemerintahan di daerah sangat dipengaruhi oleh kebijakan Kepala Daerah-nya. Struktur birokrasi yang mendukung didalamnya pun akan berperan penting dalam implementasi kebijakan Kepala Daerah tersebut (Niranjan Parida, 2015: 22.).

Politik Hukum Keterbukaan Informasi Publik di pemerintahan Kabupaten Wonogiri dimulai dengan diterbitkannya Peraturan Bupati Wonogiri Nomor 31 Tahun 2011 tentang Pembentukan Layanan Pengadaan Secara Elektronik (LPSE) Kabupaten Wonogiri. Dengan adanya peraturan bupati ini menjadi jalan untuk memulai proses pengadaan barang dan jasa secara elektronik yang lebih transparan (Kabiru Garba Muhammad, 2016: 13).

Keberhasilan Pemerintah Kabupaten Wonogiri dalam Pemeringkatan Keterbukaan Informasi Publik di Provinsi Jawa Tengah Tahun 2016 patut diapreasiasi. Hal ini menunjukkan komitmen dari Kepala Daerah untuk mewujudkan Keterbukaan Informasi Publik yang tidak terlepas dari kebijakan-kebijakan yang diambil. Hasil tersebut dapat dilihat sebagai indikator keberhasilan kebijakan yang diambil oleh Pemerintah Daerah Kabupaten Wonogiri. Namun, sebagai catatan dalam hal akuntabilitas penyelenggaraan pemerintahan, Kabupaten Wonogiri masih memperoleh nilai "CC' sampai dengan tahun 2015 (www.inspektorat.jatengprov. go.id. Diakses tanggal 28 Desember 2016). Perolehan nilai akuntabilitas Pemerintah Kabupaten Wonogiri tersebut tidak sebanding dengan capaian hasil dari Pemeringkatan Badan Publik di Provinsi Jawa Tengah. Hal ini terjadi karena kebijakan-kebijakan yang dikeluarkan oleh Pemerintah Kabupaten Wonogiri belum secara optimal dilaksanakan oleh jajaran birokrasi di dalamnya.

Kebijakan Keterbukaan Informasi Publik di Kabupaten Wonogiri belum optimal dalam tataran pelaksanaannya yang disebabkan beberapa hal yaitu luas wilayah Kabupaten Wonogiri terbesar kedua di Provinsi Jawa Tengah seluas 182.236,02 Ha dengan kondisi geografis yang kurang menguntungkan yaitu topografi yang tidak rata karena menempati daerah perbukitan yang cukup luas berdampak pada penyedian sarana dan prasarana yang mendukung persebaran informasi belum mampu 
menjangkau kesegenap pelosok wilayah kabupaten yang terdiri dari 25 (dua puluh lima) kecamatan.

Penyediaan sarana dan prasarana untuk menunjang penyebaran informasi di wilayah Wonogiri terkendala pada keterbatasan alokasi penganggaran kegiatan pada Anggaran Pendapatan dan Belanja Daerah (APBD) Kabupaten Wonogiri. Selain dari hal tersebut apabila dilihat dari kemampuan pengetahuan warga wonogiri yang bisa diukur dari indeks data Badan Pusat Statistik Kabupaten Wonogiri sebesar 6,39 (www. wonogirikab.bps.go.id, diakses tanggal 25 April 2017). Artinya bahwa tingkat pendidikan warga di kabupaten Wonogiri rata-rata selama 6,39 tahun yaitu rentang waktu tersebut hanya bisa terpenuhi dari pendidikan sekolah dasar saja. Dengan rata-rata tingkat pendidikan yang rendah maka penyerapan akan kebutuhan informasi publik dalam penyelenggaraan negara pun menjadi rendah.

Kendala lain yang dihadapi dalam penyelenggaraan pemerintah daerah terlihat dalam perilaku birokrasi di dalamnya. Komitmen untuk menyelenggarakan Keterbukaan Informasi Publik belum sepenuhnya dilaksanakan, hal ini tercermin dari masih ditemukannya SKPD yang belum menyediakan informasi publik sesuai UU KIP. Indikasi penghambat di dalam birokrasi antara lain masih dianutnya paradigma lama yaitu bahwa informasi penyelenggaraan kegiatan pemerintahan adalah informasi yang tertutup atau terbatas untuk diakses. Ditambah lagi adanya kekhawatiran bahwa dengan dibukanya informasi publik akan dimanfaatkan oleh pihak-pihak tertentu untuk memperoleh keuntungan. Pola pikir lama yang masih menjadi paradigma dalam birokrasi pemerintahan harus diubah secara berangsur-angsur. Proses perubahan pola pikir dapat dilakukan melalui pendidikan sumber daya manusia dan yang terpenting adalah kebijakan yang diambil Kepala Daerah.

Proses pembentukan hukum di ranah Politik Hukum yang terjadi dalam rangka pembentukan peraturanperaturan di daerah tidak terlepas dari adanya pertarungan-pertarungan antar kepentingan. Kebijakan kedepan yang perlu dipertimbangkan oleh Pemerintah Kabupaten Wonogiri adalah membentuk Komisi Informasi Kabupaten dalam rangka mewadahi penyelesaian sengketa informasi publik.

Para Pihak yang terkait dengan pelaksanaan Keterbukaan Informasi publik di Pemerintahan Daerah Kabupaten Wonogiri adalah Kepala Daerah beserta jajaran birokrasi didalamnya terutama yang menangani bidang Komunikasi dan Informatika serta para Pejabat Pengelola Informasi dan Dokumentasi (PPID) sesuai dengan Pasal 21 Peraturan Daerah Kabupaten Wonogiri Nomor 1 Tahun 2014 tentang Keterbukaan Informasi Publik, ditetapkan oleh Bupati. Budaya hukum sangat dipengaruhi oleh sikap masyarakat. Pemahaman hukum yang baik oleh masyarakat akan mempermudah pemerintah untuk mengambil kebijakankebijakan. Suatu proses yang panjang diperlukan untuk merubah budaya hukum masyarakat, sehingga bukan hanya perundang-undangan yang harus dibenahi namun juga budaya hukum masyarakat (Achmad Ali, 2005: 9).

Undang-Undang Nomor 14 Tahun 2008 tentang Keterbukaan Informasi Publik merupakan produk hukum yang responsif sebagai jawaban untuk penyelenggaraan pemerintahan yang baik. Pemerintah Kabupaten Wonogiri menindaklanjuti 
dengan membuat kebijakan dalam Peraturan Daerah Kabupaten Wonogiri Nomor 1 Tahun 2014 tentang Keterbukaan Informasi Publik. Pelaksanaan Politik Hukum Keterbukaan Informasi Publik di Kabupaten Wonogiri tidak lepas dari hambatan, namun dengan komitmen yang tinggi dari jajaran pimpinan daerah maka kebijakan yang responsif dapat diwujudkan.

\section{Simpulan}

1. Undang-Undang Nomor 14 Tahun 2008 tentang Keterbukan Informasi Publik (UU KIP) merupakan perwujudan pelaksanaan tugas negara sebagaimana diamanatkan dalam UUD 1945. Pemenuhan Informasi Publik merupakan salah satu Hak Asasi Manusia yang dijamin dan dilindungi oleh negara. Pembentukan UU KIP mempunyai makna yang penting secara filosofis, soiologis dan yuridis. Secara filosofis, negara sebagai pemegang mandat rakyat berkewajiban untuk memberikan jaminan dan perlindungan terhadap pemenuhan Informasi Publik. Secara sosiologis, kehadiran UU KIP merupakan wujud pemenuhan kebutuhan akan informasi publik dalam kehidupan bermasyarakat, berbangsa dan bernegara. Serta secara yuridis, tindakan pemerintah dengan menerbitkan UU KIP pada asasnya didasarkan atas kewenangan yang diberikan oleh hukum sebagai landasan penerapan Keterbukan Informasi Publik dalam membangun tata kelola pemerintahan yang baik (good governance).

2. Politik hukum Keterbukaan Informasi Publik di Pemerintah Daerah Kabupaten Wonogiri ditinjau dari substansi hukum diwujudkan dalam kebijakan dasar serta peraturan teknis pelaksanaannya. Regulasi yang perlu dibuat adalah pembentukan Komisi Informasi Daerah untuk mewadahi penyelesaian sengketa informasi publik. Dalam hal struktur telah diatur dengan pembentukan Pejabat Pengelola Informasi dan Dokumentasi (PPID). Untuk membentuk budaya Keterbukaan Informasi Publik dalam masyarakat merupakan tugas pemerintah lewat mekanisme birokrasi di dalamnya. UU KIP dibuat untuk mewujudkan hukum yang responsif yaitu dengan melibatkan masyarakat untuk berpartisipasi dalam penyelenggaraan negara untuk mewujudkan tujuan kesejahteraan sosial. Implementasi UU KIP di Kabupaten Wonogiri yang responsif tergantung dari politik hukum dan kebijakan publik yang diambil oleh pemerintah daerah.

\section{E. Saran}

1. Kemampuan mengelola informasi dengan sistem dan tata kelola yang baik menjadi faktor penting keberhasilan negara demokratis di era globalisasi. Hal ini didapatkan melalui penerapan keterbukaan informasi yang bertanggung jawab. Dalam konteks Pelayanan Publik, penerapan keterbukaan informasi publik perlu memperhatikan keadilan dan kepentingan umum. Keseimbangan antara keterbukaan informasi dan partisipasi masyarakat akan mendorong akuntabilitas dari penyelenggara negara. Diperlukan adanya penerapan sanksi administrasi dan hukum yang tegas bagi Badan Publik yang tidak memberikan informasi publik terutama informasi publik yang telah diputuskan oleh Komisi Informasi.

2. Seyogyanya untuk mewujudkan Politik Hukum Keterbukaan Informasi Publik di Pemerintah Daerah Kabupaten Wonogiri yang dapat menghasilkan produk hukum yang responsif didukung baik dari substansi, struktur, serta budaya masyarakat di Kabupaten Wonogiri. 


\section{F. Daftar Pustaka}

\section{Buku}

Abdul Latif dan Hasbi Ali. 2011. Politik Hukum. Cetakan Kedua. Jakarta: Sinar Grafika.

Achmad Ali. 2005. Keterpurukan Hukum di Indonesia. Bogor: Ghalia Indonesia.

Ambar Teguh Sulistiyani dan Yermias T. Keban. 2011. Memahami Good Governance: Dalam Perspektif Sumber Daya Manusia. Edisi Revisi Cetakan Pertama. Yogyakarta: Gaya Media.

Antonius Cahyadi dan Donny Danardono. 2009. Sosiologi Hukum dalam Perubahan. Cetakan Pertama. Jakarta: Yayasan Obor Indonesia.

King Faisal Sulaiman. 2014. Dialektika Pengujian Peraturan Daerah Pasca Otonomi Daerah. Cetakan I. Yogyakarta: Pustaka Pelajar.

Nico Andrianto. 2007. Good e-Governance: Transparansi dan Akuntabilitas Publik Melalui e-Government. Malang: Bayumedia Publishing.

Siswanto Sunarno. 2006. Hukum Pemerintahan Daerah di Indonesia. Cetakan pertama. Jakarta: Sinar Grafika.

Syakarani dan Syahriani. 2009. Implementasi Otonomi Daerah dalam Perspektif Good Governance. Cetalkan I. Yogyakarta: Pustaka Pelajar.

\section{Buletin, Jurnal, dan Tesis}

Diah Rachma Aprianty. 2016. "Penerapan Kebijakan E-Goverment dalam Rangka Peningkatan Mutu Pelayanan Publik di Kantor Kecamatan Sambutan Kota Samarinda". E-Jurnal Ilmu Pemerintahan. Volume 4 Nomor 4.
Diaswati Mardiasmo. 2007. “Good Governance Implementation and International Alligment: The Case of Regional Goverments in Indonesia". Thesis for Master of Business Qeensland University of Technology Brisbane Australia.

Endang Retnowati. 2012. "Keterbukaan Informasi Publik Dan Good Governance (Antara Das Sein Dan Das Sollen)". Jurnal Perspektif. Edisi Volume 17 Nomor 1.

E. Shepherd, A. Stevenson, dan A. Flinn. 2010. "Information Governance, Records Management, and Freedom of Information: A Study of Local Government Authorities in England". Government Information Quarterly. Volume 27 Issue 4.

Kabiru Garba Muhammad. 2016. "Role of Civil Society Organisations on the Enforcement of Public Procurement Law in Nigeria - A Case Study of Sokoto State". International Journal of Law. Volume 2 Issue 1.

Tim Penyusun Komisi Informasi Pusat Republik Indonesia, Indonesian Center for Enviromental Law (ICEL) dan Yayasan Tifa. 2009. “Anotasi UndangUndang Nomor 14 Tahun 2008 tentang Keterbukaan Informasi Publik". Edisi 1. Jakarta: Gajah Hidup Print.

Laperdrix Marie. 2011. "The Freedom of Information Act 2000: An Updated Literature Review (2009-2011)". International Centre for Archieves and Records Management Research.

Meissy Janet Naeku. 2016. "Environmental Law and Governance as Antecedent Factors to Sustainable Development in Developing States". International Journal of Law. Volume 2 Issue 5. 
Niranjan Parida. 2015. "The Role and Importance of Civil Servants in India - A Socio Legal Study". International Journal of Law. Volume 1 Issue 1.

Nunuk Febriananingsih. 2012. "Keterbukaan Informasi Publik Dalam Pemerintahan Terbuka Menuju Tata Pemerintahan Yang Baik". Jurnal Recht Vinding. Volume 1 Nomor 1.

Siska Setiya Dewi, dkk. 2014. "Implementasi Kebijakan E-Procurement di Kabupaten Wonogiri”. Journal of Public Policy and Management Review. Volume 4 Nomor 1.

\section{Data Elektronik}

http://www.dprd-wonogirikab.go.id. Diakses tanggal 7 Desember 2016.

https://www.komisiinformasi.go.id/news/ view/laporan-hasil-pemeringkatan-2014. Diakses tanggal 14 Oktober 2016. www.inspektorat.jatengprov.go.id. Diakses tanggal 28 Desember 2016.

www.kipjateng.jatengprov.go.id. Diakses tanggal 17 Maret 2017.

www.kpk.go.id, diakses pada tanggal 24 April 2017.

www.wonogirikab.bps.go.id, diakses tanggal 25 April 2017.

Sofian Munawar Asgart. Keterbukaan Informasi Publik dalam Perspektif Governability. http://www.kompasiana. $\mathrm{com} /$ sasgart/keterbukaan- informasipublik-dalam-perspektif-governability 550d9689813311c925b1e2c0. Diakses tanggal 15 November 2016.

Surianto. Dampak Positif dan negatif UU KIP Bagi Pemerintah dan Masyaraka. www.babelprov.go.id. Diakses tanggal 20 Desember 2016. 